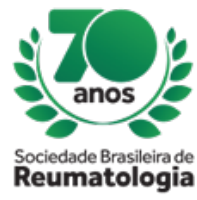

\title{
POMPE DISEASE LATE ONSET AS A CAUSE OF DIAPHRAGMATIC FAILURE
}

Rodrigo Antunes Silveira (Hospital das Clinicas luzia de pinho melo -UMC, Mogi das Cruzes, SP, Brasil), Cecilia Davila Chambi (Hospital das Clinicas luzia de pinho melo -UMC, mogi das cruzes, SP, Brasil), Danielli Aparecida Selegatto (Hospital das Clinicas luzia de pinho melo -UMC, mogi das cruzes, SP, Brasil), Isadora Melo Zambuzzi (Hospital das Clinicas luzia de pinho melo-UMC, mogi das cruzes, SP, Brasil), Nicolas Nisiyamamoto Barboza (Hospital das Clinicas luzia de pinho melo -UMC, mogi das cruzes, SP, Brasil), Monica Maria Canavezi (Hospital das Clinicas luzia de pinho melo -UMC, mogi das cruzes, SP, Brasil), Pollyana Veronica Cortelassi (Hospital das Clinicas luzia de pinho melo -UMC, mogi das cruzes, SP, Brasil), Maysa Alecseev de Melo (Hospital das Clinicas luzia de pinho melo -UMC, mogi das cruzes, SP, Brasil), Beatriz Lopes Galisteu (Hospital das Clinicas luzia de pinho melo -UMC, mogi das cruzes, SP, Brasil), Philipe Sousa Silveira (Hospital das Clinicas luzia de pinho melo -UMC, mogi das cruzes, SP, Brasil), Bruna Verri De Martino (Hospital das Clinicas luzia de pinho melo -UMC, mogi das cruzes, SP, Brasil), Yolanda Valeria de Souza (Hospital das Clinicas luzia de pinho melo -UMC, mogi das cruzes, SP, Brasil), Beatriz Jardim de Siqueira Branco (Hospital das Clinicas luzia de pinho melo -UMC, Mogi das Cruzes, SP, Brasil), Debora Cristina Fortes Moreira (Hospital das Clinicas luzia de pinho melo -UMC, mogi das cruzes, SP, Brasil), Flavia Macedo Quintao de Sa (Hospital das Clinicas luzia de pinho melo -UMC, mogi das cruzes, SP, Brasil), Jacqueline Kaori Tozaki Tamada (Hospital das Clinicas luzia de pinho melo UMC, mogi das cruzes, SP, Brasil), Daniela Gomes Chicre Oliveira (Hospital das Clinicas luzia de pinho melo -UMC, mogi das cruzes, SP, Brasil), Sergio Augusto Yukio Hissayassu (Hospital das Clinicas luzia de pinho melo -UMC, mogi das cruzes, SP, Brasil), Ana Carolina Dias Costa (Hospital das Clinicas luzia de pinho melo -UMC, mogi das cruzes, SP, Brasil), Livia Geovana Falcao Vieira Celestino (Hospital das Clinicas luzia de pinho melo -UMC, mogi das cruzes, SP, Brasil), Gabriel Domingues dos Santos (Hospital das Clinicas luzia de pinho melo -UMC, mogi das cruzes, SP, Brasil)

\section{BACKGROUND}

Pompe disease (PD) is a genetic disease due to deficiency of the enzyme alpha-glucosidase acid (GAA) that occurs in several age groups and may have varied clinical evolutions

\section{CASE REPORT}

CAS, a 44-year-old man from Biritiba-Mirim (SP), a mechanic, sought our service for progressive dyspnea one month ago and worsened in the last week associated with cough, weight loss, lower limb weakness and dysphagia. Deny fever. Physical examination: REG, CHAAA, LOTE, dyspneic, PA:121X76mmHg, FC:94bpm, FR:18irpm, Sat:81\%, Weight:70kg and peripheral cyanosis. MV + and decreased in the left pulmonary base without RA. Grade 2 muscular strength in lower members (LM) and normal in upper limbs. No further changes. Patient evolved with CNF associated with dyspnea worsening, requiring IOT and intensive clinical support. Investigations: HMG with Hb:15.4 Ht:52.4 VCM:82, L:4700 and CPK:320. RX of thorax: bilateral diaphragmatic kneeling / absence of condensation or pneumopathy. Spirometry before hospitalization: restrictive disorder grade3. ENMG:normal. Patient evolved with tracheostomy and mechanical ventilation without improvement of respiratory patterns. Due to diaphragmatic involvement, CPK that was slightly altered without the use of statin or other medications, without other diseases that explained the symptoms and with normal ENMG, the hypothesis of PD was suggested, which was confirmed by a molecular test carried out in the Laboratory of Inborn Errors of Metabolism (LEIM) of Federal University of São Paulo.PD is a rare genetic disease with a prevalence of about 1: 30,000 that is deficient in GAA, leading to accumulation of glycogen in various organs and tissues throughout the body. It may occur in children or adults, determining a large genotype and phenotype variety according to age: children commonly develop with cardiomyopathy, hypotonia and hepatomegaly as more frequent manifestations; in adults, diaphragmatic and skeletal muscle involvement in LM is commonly observed. 
In our case, the clinical presentation was relatively classic, thus indicating the enzymatic replacement in conjunction with general interdisciplinary measures.

\section{CONCLUSION}

PD should always be remembered in cases of inflammatory myopathies that are not responsive to usual treatments and also in patients with muscular involvement of the diaphragm, liposuction of paravertebral musculature and restrictive disorder without definite cause in spirometry. Drug treatment involves enzyme replacement therapy associated with multidisciplinary follow-up. Gene therapy is future prospect. 